\title{
Teaching General English in Academic Context: Schema-Based or Translation-Based Approach?
}

\author{
Ebrahim Khodadady \\ Department of English Language and Literature, Ferdowsi University of Mashhad, Iran \\ E-mail: ekhodadady@um.ac.ir
}

Seyyed Mohammad Alavi

Department of English Language and Literature, University of Tehran, Iran

E-mail: mohammad.alavi@gmail.com

\section{Reza Pishghadam}

Department of English Language and Literature, Ferdowsi University of Mashhad, Iran E-mail: rpishghadam@gmail.com

Mohammad Saber Khaghaninezhad (Corresponding author)

Department of English Language and Literature, Ferdowsi University of Mashhad, Iran

A1C 1Y6, 25 Young street, St. John's, NL, Canada

Tel: 1-779-722-7784_ E-mail: saber.khaghani@yahoo.com

Received: January 1, 2012 Accepted: January 7, 2012 Published: March 1, 2012

doi:10.5296/ijl.v4i1.1213ＵRL: http://dx.doi.org/10.5296/ijl.v4i1.1213

\begin{abstract}
This study is one of the first attempts to investigate the effect of schema-based general English teaching and testing on English language learning in an Iranian academic context. A total of 90 undergraduate theology students studying general English at Ferdowsi University of Mashhad (FUM) were assigned to an experimental and a control group. For the same
\end{abstract}




\section{Macrothink}

course book two instructional approaches were adopted during an academic semester; schema-based instruction (SBI) for experimental and translation-based instruction (TBI) for control groups. At the semester's commencement a schema-based cloze multiple choice item test (MCIT) was developed on the textbook and administered as a pre-test to ensure that the experimental group did not differ significantly from the control group. The same test was administered again at the semester's termination along with an unseen reading comprehension test (URCT) to find out which approach was more effective. Final results showed that the performance of the experimental group was superior to the control group on both MCIT and URCT. The implications of the findings are discussed in the light of teaching English as a foreign language within an academic context.

Keywords: Schema-based instruction, Translation-based instruction, Schema-based cloze multiple choice items tests, Unseen reading comprehension test 


\section{Introduction}

Inspired by Plato's elaboration of the Greek doctrine of ideal types - such as the perfect circle that exists in the mind but which no one has ever seen, Kant (1781) developed the notion further and employed the word "schema" in his writings. For example, he describes the "dog" schema as "a mental pattern which can delineate the figure of a four-footed animal in a general manner, without limitation to any single determinate figure as experience, or any possible image" (p. 41) that can be represented in reality. Early developments of the idea in psychology emerged with the Gestalt psychologists and Piaget (1973). However, it is with the work of Bartlett (1932) that the term came to be used in its modern sense, 'This learning theory views organized knowledge as an elaborate network of abstract mental structures which represent one's understanding of the world' (p. 26).

Bartlett's proposal was neglected in America during the behaviouristic era until its wholesale recapitulation in Neisser's (1967) massively influential Cognitive Psychology. Neisser's work led to the ubiquity of the term in psychology, and its extension to other disciplines, notably the cognitive and computational sciences. Since that time, many other terms have been used as well, including "frame," "scene," and "script". Schemata are important not just in interpreting information, but also in decoding how that information is presented. Schemata can be activated in text structures (Driscoll, 1997; Halliday \& Hassan, 1989). Readers use their schematic representations of text (narrative, compare/contrast, cause/effect, etc.) to help them interpret the information in the text. It can also be activated through related image-presentation (Morimoto \& Loewen, 2007) while both of these two types of activation is culturally determined according to Kaplan (2007).

Schema Theory, unlike some other learning theories such as "behaviorism" or "cognitive dissonance" does not seek to explain the acquisition of only certain types of behaviors or attitudes. Rather instructional strategies based on the theory, can be applied to any learning situations. Its ability to explain how numerous and different types of knowledge is learned and to suggest appropriate instructional strategies also makes Schema Theory an effective and applicable rationale for educators and instructional designers.

So far, what was said about schemata, the plural of schema, and Schema Theory was a general, universally-accepted description. The term schema, however, has a different and narrower definition in the present study. Schemata are all linguistic manifestations employed by speakers/writers' (henceforth addressers) to convey their intended message. These linguistic items are selected and produced in a given text on the basis of their world knowledge, expectations, personal attitudes, feelings and experiences. The reception or comprehension of the textual schemata is the function of the interaction between addressers and listeners/readers (henceforth addressees). Hence, the degree of comprehending each and all schemata depends on the amount of relevant background knowledge shared by addressers and addressees (Khodadady, 1997).

Khodadady (2008) provided an operationalized definition of schemata so that reading comprehension ability can be measured as accurately as possible. He defined a schema as a 
single word used along with other words to form an authentic text uttered or written for being heard or read under given conditions at specific places and time. The demarcation of schema as the building block of authentic textual products provides linguists and language teachers alike with an objective measure to form their analyses and pedagogy on, respectively.

Although the efficacy of Schema Theory has been documented in few other studies in the context of private language institutes (e.g. Khodadady, Pishghadam \& Fakhar, 2010), it seems an educational necessity to investigate its potential for academic centers considering the huge population of Iranian university students. This cluster of studies, which are in the same direction, may confirm the superiority of Schema Theory over the current common language teaching and testing approaches in Iran and thus offer an alternative to improve their quality of education.

This study is an attempt to investigate the effect of schema-based general English teaching and testing in an Iranian academic context. It seems that general English courses at Iranian universities are taught by employing Grammar Translation Method_ 'emphasizing vocabulary memorization, explicit grammar instruction, using students' L1 and the direct translation of texts into L1. This prevalent approach of language teaching is called translation-based instruction (TBI) throughout this study designed to answer the following research questions:

$>$ Is there any significant difference in the performance of translation and schema-based instruction groups on the final schema-based cloze multiple choice post-test?

$>$ Is there any significant difference in the performance of translation and schema-based instruction groups on the final unseen reading comprehension test?

\section{Literature review}

All human beings possess categorical frames or scripts which they use to interpret the world. New information is processed according to how it fits into these scripts, called schemata. They can be used not only to interpret but also to predict situations occurring in our environment. Information that does not fit into these schemata may not be comprehended properly and adequately. In contrast to Ausubel's (1968) "Meaningful Receptive Learning Theory", the learners in schema theory actively build and revise their schemata in the light of new information. Each individual's schema is thus unique and depends on that individual's experiences and cognitive processes. Ausubel postulated a hierarchical organization of knowledge where the learner more or less attached new knowledge to the existing hierarchy. In this representation, memory is driven by structure as well as meaning. Knowledge in Schema Theory is not only stored hierarchically but also meaning-driven and probably represented propositionally (Plastina, 2000). These networks of propositions are actively constructed by the learner and expressed whenever necessary. For example, when we are asked to recall a story that we were told, we are able to reconstruct the meaning of the story, but usually not the exact sentences- or even often the exact order in which the story unfolds. We remember the story by actively constructing a meaningful network of schemata stored in our memory. 


\subsection{Schema-based Instruction}

One of the oldest findings in educational research is the strong relationship between vocabulary knowledge and reading comprehension (Hart \& Risley, 1995). Word knowledge is crucial to reading comprehension and determines how well students will be able to comprehend the texts they read in middle and high school. Vocabulary experts agree that adequate reading comprehension depends on a person already knowing between 90 and 95 percent of the words in a text (e.g. Hirsch, 2003). Knowing at least 90 percent of the words enables the reader to get the main idea from the reading and guess correctly what the unfamiliar words mean, and thus will help them learn their meaning. Readers who do not recognize at least 90 percent of the words will not only have difficulty comprehending the text, but they will miss out on the opportunity to learn new words.

According to Khemlani (2000), Schema Theory proposes that when individuals obtain knowledge, they attempt to fit that knowledge into some structure in memory that helps them make sense of that knowledge. It also proposes that individuals break down information into generalizable chunks which are then categorically stored in the brain for later recall. Schema Theory is an active coding technique necessary for facilitating the recall of knowledge. As new knowledge is perceived, it is coded into either pre-existing schema or organized into a new script. In essence schemata are organized mental structures represented in linguistic units that aid the learner's ability to understand and associate with what is being presented to them.

Schema-based instruction (SBI) can be assumed as a cover term for a cluster of language teaching techniques which attempt to relate the new linguistic items to be acquired by learners to the author's schemata through various less demanding contexts and modes such as definitions and explanations provided orally or visually. This language teaching approach is based on the premise that readers of a given text will understand it best if they are familiar with the sense of each and all words, i.e., schemata, employed by the writer of the text. Instead of leaving the learners to themselves to look up the contextual meaning of the schemata, they need to be read by the readers and discussed with the teacher within the contexts of the texts in which they appear and whatever modes possible so that the learner's understanding of the schemata would approach to that of the writer. This type of instruction is also called contextual vocabulary instruction (Khodadady, 1997).

The dependence of schema-based instruction on all the schemata comprising authentic texts entails the teachers' familiarity with their domain, genera, species and types and teaching them to their learners right at the beginning of a course. According to Khodadady (2008), schemata can be generally classified into three domains, i.e., semantic, syntactic and parasyntactic;

Semantic schemata are similar to "open - class items" (Quirk, Greenbaum, Leech \& Svartvik, 1985 , p.42) consisting of four genera, i.e., adjective, adverbs, nouns and verbs. However, while the open-class items include words as they appear in isolation, e.g., in dictionaries, semantic schemata represent the authors' background knowledge of semantic schemata as they joined together by syntactic and parasyntactic schemata to express the authors' intended messages. Since the messages are expressed through semantic schemata, they are many in 
type but few in frequency.

Syntactic schemata whose isolated counterparts are traditionally known as "closed - class items" (Quirk, Greenbaum, Leech \& Svartvik, 1985, p.44) consist of auxiliaries, conjunctions, determiners, prepositions and pronouns as their genera. In contrast to semantic schemata, syntactic schemata are few in type but many in frequency and thus provide addressers with a definite and finite set of items through which they can connect semantic schemata together in order to express what their authors intend to convey. Syntactic schemata are, therefore, limited in type and are basically employed to constrain the addressers' semantic schemata within various variables including place and time.

The third domain of schemata is parasyntactic and comprises various genera such as abbreviations, names, numerals, and para-adverbs. Parasyntactic schemata are similar to syntactic schemata because they depend on and attach to semantic schemata in order to constrain them within intended variables such as numbers and manners. Some parasyntactic schemata like numeral are, however, similar to semantic ones in that they are many in type but few in frequency. Table 1 presents the parasyntactic as well as semantic and syntactic domains and their genera.

Table 1. Schema domains and genera

\begin{tabular}{|l|l|l|l|l|l|}
\hline Domains & \multicolumn{5}{|c|}{ Genera } \\
\hline Semantic & Adjectives & Adverbs & Nouns & verbs & \\
\hline Syntactic & Conjunctions & Determiners & Prepositions & Pronouns & Syntactic verbs \\
\hline Parasyntactic & $\begin{array}{l}\text { Abbreviations } \\
\text { Particles }\end{array}$ & $\begin{array}{l}\text { Names } \\
\text { Interjections }\end{array}$ & Numerals & Para-adverbs & Symbols \\
\hline
\end{tabular}

As a new approach to teaching English as a foreign language, the SBI provides learners with a hieratical and holistic view of language by presenting the three semantic, syntactic and parasyntactic domains right at the beginning of the term and helping them realize that English is learnable and what they need is just to master the domains and their genera by resorting to their reading comprehension ability.

Having gained confidence in learning English by mastering only three domains and their genera, SBI gains momentum. Learners are asked to read the passage and assign their schemata to the three domains and their genera. As they do so they start asking what the differences among the schemata comprising a given genus such as adjectives are. At this phase, the researcher offers the species of the genera shown in Table 2. (The schema-based instructor must analyze and categorize all the schemata of whatever texts they teach on the basis of a more detailed codification system consisting of 119 codes. Interested readers can contact the corresponding author for the codes and their examples). 
Table 2. The species comprising the genera of schema domains

\begin{tabular}{|c|c|}
\hline Genera & Species \\
\hline Adjectives & Agentive, Comparative, Dative, Derivational, Nominal, Simple, Superlative \\
\hline Adverb & Comparative, Derivational, Simple, Superlative \\
\hline Nouns & $\begin{array}{l}\text { Adjectival, complex, compound, conversion, derivational, gerund, nominal, } \\
\text { simple }\end{array}$ \\
\hline Verb & Complex, derivational, phrasal, simple, slang \\
\hline Conjunctions & Phrasal, simple \\
\hline Determiners & $\begin{array}{l}\text { Demonstrative, Interrogative, Numeral, Possessive, Quantifying, Ranking, } \\
\text { Specifying }\end{array}$ \\
\hline Prepositions & Complex, Compound, Phrasal, Simple \\
\hline Pronouns & $\begin{array}{l}\text { Demonstrative, Emphatic, Interrogative, Object, Possessive, Reflexive, } \\
\text { Relative, Subject, Unspecified, Specified }\end{array}$ \\
\hline $\begin{array}{l}\text { Syntactic } \\
\text { verbs }\end{array}$ & $\begin{array}{l}\text { Present Auxiliary, Present Perfect Auxiliary, Present Perfect Continuous } \\
\text { Auxiliary, Past Model Auxiliary, Past Perfect Model Auxiliary, Present } \\
\text { Model Auxiliary, Present Perfect Model Auxiliary, Future Perfect } \\
\text { Continuous Auxiliary, Past Phrasal Auxiliary, Past Perfect Phrasal Auxiliary, } \\
\text { Past Perfect Continuous Auxiliary, Present Phrasal Auxiliary, Model } \\
\text { (Present) } \\
\text { Model (Past) }\end{array}$ \\
\hline Abbreviations & Abbreviations; acronyms \\
\hline Interjections & Simple \\
\hline Names & Full, Labeling, Organizational, Single, Titles \\
\hline Numerals & Alphabetic, Digital, Roman, Year \\
\hline Para-adverbs & $\begin{array}{l}\text { Additive, Contrasting, Emphatic, Exemplifying, Frequency, Intensifying, } \\
\text { Interrogative, Location, Manner, Negation/Approval, Prepositional, } \\
\text { Referential, Time }\end{array}$ \\
\hline Particle & Complex, Simple \\
\hline Symbols & Conventional, Scientific \\
\hline
\end{tabular}

Facing the learners in the SBI group, it was, for example, asked who wanted to read the title and first paragraph of lesson one given below. One of the learners volunteered, as she was reading the text, the teacher wrote down the schemata mispronounced so that they could be discussed more. Since the schema particular was, for instance, mispronounced the reader was asked what type of schema it was. She said it was an adjective and meant special, however, she could not understand what role the preposition in had in the sentence. When it was said that a preposition preceding an adjective can change it into adverb, she immediately uttered particularly, specially. In response to the question, "Why had the writer used in particular?" 
She said that he wanted to describe the action of mentioning.

The study of the religions of the world is of great interest and importance. Three reasons for this may be mentioned in particular. Far more is known about the great religions of the world today than ever before, outside the regions in which each prevails; a great deal of impartial and accurate study during the last hundred years makes it possible to know the faith of others as never previously. It is no longer permissible to speak, as did medieval miracle plays, of Muslims worshipping an idol called Baphomet! And it should be no longer asserted that the Chinese adore Confucius, or that Christians regard the Virgin Mary as the second of three gods.

As another example, for teaching the following paragraph, since the schema revival was mispronounced the reader was asked what type of schema it was. She said it was a noun which is built by - al to the verb revive and meant recovery, however, she could not understand what role the preposition of had in the sentence. When it was said that an of following a noun will give the sense of possession, she immediately uttered like teacher of the class with a smile.

A third reason for the importance of this subject is the revival of life in many of the world's religions. With the rise of nationalism and the recovery of self - government, many eastern lands have turned again to the religion on which their culture has been based. With the example of Christian missions before them Buddhism and Islam, themselves historically missionary religions, have begun to send literature and envoys to other people. Even in Hinduism and Sikhism a similar awakening and outward looking is apparent. The modern world has not yet done with religion. Our scientific age, with its pride and its uncertainties, is only just beginning to realize the strength of the faiths that men have held dear for thousands of years and that are reviving today.

The teacher was watching all the learners while the reader was explaining her answer. This was done to find out whether the whole class was attentive to the interaction or not! In order to emphasize the necessity of their constant attention and participation, it was announced that at the beginning of the next session, the meaning of all the schemata covered in the previous sessions and their domains and genera will be asked and the responses will be scored as announced in the course outline (10\% of the final score).

\subsection{Translation-based Instruction}

The instruction of general English as a course in Iranian universities is very close to Grammar Translation Method (GTM) if not identical. GTM is undoubtedly the oldest, the easiest and understandably the most common approach for teaching English (Howatt, 1984). Although many of its shortcomings have been revealed, it is the prevalent doctrine for general English courses tertiary educational centers in Iran. This is because it is the easiest approach for the teachers and here are some theoretical supports for the application of GTM in second and foreign language learning contexts. There seems, for example, to be a preference, explicitly stated or not, for inter-lingual strategies, which utilize the L1 in the form of a bilingual dictionary, cognates, or L1 translation equivalents, often associated with 
word lists, over intra-lingual strategies, which involve the use of linguistic means of the target language such as synonyms, definitions, or linguistic contexts among many teachers and researchers. As pointed out by Schmitt (1997), intra-lingual strategies are, however, 'pedagogically correct' because they are consistent with principles of communicative language teaching or comprehensive input.

Although Freeman (2000) noted, 'a fundamental purpose [of the TBI] is to read literature and literary prose [because it] is superior to spoken language.' (p.13), many teachers and students alike believe that translation into their first language helps them understand the text easily. Besides, since the written language is considered to be more fundamental, learner's mentality and intellect is to develop by memorizing the needed rules and words and applying this knowledge in writing and interpreting of the selected texts (Richards \& Rodgers, 2001). More on the educational side, it can be pointed out that the students should be able to translate a text, write answers to the reading text and then learn grammar deductively (Freeman, 2000).

As the oldest method of language teaching, the Translation-based Instruction (TBI) is still in use in many parts of the world. It maintains the mother tongue of the learner as the reference particularly in the process of learning the second/foreign languages. The method emphasizes the study of grammar through deduction, i.e., learning its rules and applying them to sentences. A contrastive study of the target language with the mother tongue gives an insight into the structure not only of the foreign language but also of the mother tongue. Chastain (1971) referred to some of TBI's advantages as follows:

- Translation interprets the words and phrases of the foreign languages in the best possible manner.

- The phraseology of the target language is quickly explained. Translation is the easiest way of explaining meanings or words and phrases from one language into another. Any other method of explaining vocabulary items in the second language is found time consuming. A lot of time is wasted if the meanings of lexical items are explained through definitions and illustrations in the second language. Further, learners acquire some short of accuracy in understanding synonyms in the source language and the target language.

- The structures of the foreign languages are best learned when compared and contrast with those of mother tongue.

- Teacher's labor is saved. Since the textbooks are taught through the medium of the mother tongue, the teacher may ask comprehension questions on the text taught in the mother tongue. Pupils will not have much difficulty in responding to questions on the mother tongue. So, the teacher can easily assess whether the students have learned what he has taught them. Communication between the teacher and the learner does not cause linguistic problems. Even teachers who are not fluent in English can teach English through this method.

For teaching the control group by employing the TBI, as a sample, the paragraph given in section 2.1 was read loud by the teacher as the learners in the group followed him attentively with their books open. Then, it was translated into Persian sentences by sentences. A brief 
description was also presented for each of the great characters mentioned in the text such as Confucius and Virgin Mary. The students' grammatical questions were welcome and answered by the teacher while the Persian was the medium of all instructional activities throughout the semester.

\subsection{Schema-based Tests}

Khodadady (1997) was among the first researchers who realized the difficulty of pinpointing an objective unit of language from a psychometric point of view as he embarked on developing multiple choice item tests to measure the reading comprehension ability of native and non-native university students. According to Khodadady (1999), almost all multiple-choice items measuring reading comprehension ability address not sentences but the words comprising the sentences. For example in the following item, if the test taker perceives that the missed word should be a noun, then, other three choices would be omitted automatically. Hence the test taker can select the only choice left (which is a noun) and answer the item correctly without comprehending the meaning of the text even without knowing the meaning of the selected word.

There is an excellent book entitled How to Argue with a Conservative that gives the reader tools necessary for success in argumentation. At times you may have to engage in a verbal skirmish with $\mathrm{a}(\mathrm{n})$.............. It would be to your advantage if you had the proper words at your fingertips. (Bromberg, 2004, p. 112)
a) amicable
b) virulent
c) bigot*
d) haunt

Since words are as abstract as sentences, nobody has been able to state what alternatives should be given along with the correct response to measure test takers' reading comprehension ability. Almost all scholars in testing have, however, provided some suggestions for test designers to prepare their multiple choice items. Farhady, Jafarpoor and Birjandi (1994), for example, offered the following 11 guidelines:

1. The stem should be quite clear and state the point to be tested unanimously.

2. The stem should include as much of the item as possible.

3. Negative statements should be avoided because they are likely to be ignored by the examinees.

4. All of the alternatives must be grammatically correct by themselves and consistent with the stem.

5. Every item should have one correct and clearly best answer.

6. All distracters should be plausible; they should be of similar length and level of difficulty.

8. Using "all of the above" or "none of the above" as an alternative is not recommended.

9. Correct responses should be distributed approximately equally and randomly among the alternatives.

10. The stem should not provide any grammatical clue which might help the examinee find the correct response without understanding the item.

11. The stem should not start with a blank. 
As can be seen, none of the suggestions above addresses the nature of choices offered as possible answers and where they should come from. This very allusive nature of distracters has rendered the construction of multiple - choice items very notorious and extremely difficult (Hughes, 1989). To avoid the problem, some scholars have, therefore, suggested that well-functioning multiple choice items be developed by experts (Bachman, Davidson, Ryan, \& Choi, 1995). Khodadady (1997) and Khodadady and Herriman (2000) employed schema theory to explain the nature of alternatives employed in multiple choice item tests and employed the term competetives to replace distracters as their traditional counterparts. In contrast to distracters, competitives have semantic, syntactic and discoursal relations with the keyed response of a schema-based cloze multiple choice item and thus measure not only test takers' vocabulary and grammatical knowledge but also their reading comprehension ability.

For example, in the following item the keyed response of the item, i.e., public, is viewed as a schema whose understanding and selection will depend not only on the readers' background knowledge of the schema public itself but also on the other schemata among which it appears in the text. The schemata people and transport, for example, precede and follow the deleted schema public in the first sentence given below and thus calls for the test takers' background knowledge to decide why the other three choices are not appropriate to be chosen. The difference between this item and other traditional cloze multiple choice items is that the three choices, i.e., general, popular and common, given with the keyed response, i.e., public, have semantic and syntactic relationships with each other and thus call for understanding not only the linguistic context in which the deleted word appears but also the three choices offered. There is usually no semantic relationship among the choices of traditional cloze MCITs (Khodadady 1997, 1999).

In the future, people will have to use transport much more. They won't be able to drive into the heart of many towns (Gairns \& Redman 1996, p. 8).
A. general
B. popular
C. public
D. common

According to Kieffer (1979) while the importance of Schema Theory to ESL/EFL instruction seems to have been aptly and amply demonstrated, its relevance to testing models has yet to be verified. It is argued that no verification has been made so far simply because schema theory has traditionally been approached macrostructurally by focusing on broad terms such as genres and scripts. Schema-based language tests will accommodate both holistic and discrete principles of testing if they are designed microstructurally, i.e., on the words comprising the texts. It is also maintained that the schema-based cloze MCITs do enjoy the advantages enumerated by Keiffer as follow:

1- They would engage the conceptual processes for the students; freeing him or her for the decoding task at hand. Providing the rhetorical schema would allow students to focus on the content. This is supported by Carrel's research (1984) in which ESL/EFL readers who recognized the text's original discourse type and utilized this type to organized their own recall were able to reproduce more information from the original 
text. In addition, since L1 schema may differ sharply from English, providing the schema for ESL/EFL learners will reduce the element of cultural bias of tests.

2- Since recall, after the introduction, conforms to the idea structure rather than the linear organization, schema-based tests would be in harmony with the psycholinguistic model of processing. This makes them more comfortable for the student and more valid for the evaluator.

3- It would ensure that a student's grade correlates closely with her/his understanding and he can use the learnt words actively in communication.

4- Usage of Academic, test formal items will result in a polished language and will be a good basis for course-leaving examination. (p.23)

\section{Method}

\subsection{Participants}

The study included two separate but complementary phases; for the first phase which was a pilot investigation of the implementation of schema-based testing approaches, some 64 university students who had taken the general English course were recruited. They have been of approximately similar language proficiency levels _ participants have undergone English learning for at least 5 years at school and have passed the same university entrance examination_ and singled out inspired by intact group design. They were students of theology and Islamic studies at Ferdowsi University of Mashhad, Iran. Forty eight participants of this phase of the study were female and 16 were male English learners while their ages ranged from 18 to 43 . The participants of the second phase were 78 female and 12 male general English learners whose ages ranged from 18 to 26 . They were categorized into two general categories of TBI and experimental.

\subsection{Materials}

The textbook which was used for this study was English for the students of Theology and Islamic sciences (Ataii \& Dasterjerdi, 2002), which is a common source for general English courses at theology faculties in Iran. Each lesson of the book consists of a related reading comprehension followed by a set of true/false items, few multiple-choice items, a couple of fill-in-blanks exercises for newly learnt vocabularies through the passage, and a passage and some of its difficult words to be translated. For the study to be performed, a schema-based instruction and assessment of the course book's texts was needed. Following Khodadady (1997, 1999) and Khodadady and Herriman (2000), all the comprising words (schemata) of eight lessons of the book were schematically categorized and codified into three domains and their constituting genus types. Table 3 shows the frequency of different genus types on the basis of which the proportion of the study's tests items was determined. 
Table 3. Schemata type and frequency of the study's course book

\begin{tabular}{|l|l|l|l|l|l|l|l|l|l|l|l|l|l|l|l|l|l|}
\hline \multicolumn{1}{|c|}{} & Adj & Adv. & Noun & Verb & Con & Det. & Prep. & Pro & $\begin{array}{l}\text { Syn. } \\
\text { verb }\end{array}$ & Abb. & Name & No. & Para-adv. & Par & Sym & Total \\
\hline LESSON & $\begin{array}{l}\text { L } \\
1\end{array}$ & 78 & 13 & 149 & 87 & 7 & 25 & 21 & 16 & 14 & 5 & 23 & 24 & 22 & 1 & 1 & 486 \\
\hline & L & 77 & 14 & 138 & 83 & 7 & 28 & 16 & 26 & 11 & 5 & 16 & 24 & 24 & 2 & 0 & 471 \\
\hline & $\begin{array}{l}\text { L } \\
3\end{array}$ & 99 & 16 & 203 & 152 & 7 & 22 & 25 & 26 & 14 & 4 & 4 & 36 & 20 & 1 & 0 & 629 \\
\hline & $\begin{array}{l}\text { L } \\
4\end{array}$ & 82 & 12 & 210 & 114 & 9 & 21 & 24 & 25 & 13 & 6 & 6 & 34 & 22 & 3 & 0 & 581 \\
\hline & $\begin{array}{l}\text { L } \\
5\end{array}$ & 75 & 10 & 196 & 115 & 8 & 17 & 22 & 24 & 14 & 5 & 9 & 33 & 22 & 2 & 0 & 552 \\
\hline $\begin{array}{l}\mathrm{L} \\
6\end{array}$ & 78 & 16 & 199 & 118 & 8 & 21 & 22 & 25 & 11 & 6 & 15 & 36 & 24 & 1 & 0 & 580 \\
\hline $\begin{array}{l}\text { L } \\
7\end{array}$ & 100 & 16 & 192 & 117 & 8 & 23 & 18 & 27 & 18 & 8 & 15 & 29 & 25 & 1 & 0 & 598 \\
\hline $\begin{array}{l}\text { L } \\
8\end{array}$ & 58 & 12 & 169 & 119 & 9 & 28 & 17 & 33 & 19 & 3 & 14 & 28 & 22 & 1 & 0 & 532 \\
\hline
\end{tabular}

\subsection{Instruments}

Two tests were developed in the study to fulfill two functions, i.e., schema-based cloze multiple choice item test and an unseen reading comprehensions test.

\subsubsection{Schema-Based Cloze Multiple Choice Item Test}

A schema-based cloze multiple choice item (MCIT) was developed on the passages to be covered during the term in order to achieve two purposes. It was administered as a pre-test at the beginning of the term to find out whether the two TBI and SBI groups were at the same entry level and thus did not differ significantly from each other. And it was administered at the end of the term as an achievement test in order to find out whether the learners had learned the material taught. Following Khodadady (1997, 1999) and Khodadady and Herriman (2000), all the words comprising these paragraphs (as schemata) were put into three domains of semantic, syntactic and parasyntactic and their subcategories. After the schematic categorization, eighty schemata of these paragraphs were deleted and replaced with numbered blanks. For each blank four choices were offered. As Table 3 presents the number of each domain items was determined in accordance with the proportion of these domains and their subcategories in the course book. 
Table 4. Descriptive statistics of schema types comprising the course book

\begin{tabular}{|l|c|c|c|c|}
\hline Schema domains of the whole text & Number & Percentage & Number of items & Percentage \\
\hline Semantic & 3121 & $70 \%$ & 56 & $70 \%$ \\
\hline Syntactic & 730 & $17 \%$ & 14 & $17 \%$ \\
\hline Parasyntactic & 578 & $13 \%$ & 10 & $13 \%$ \\
\hline Total & 4429 & $100 \%$ & 80 & $100 \%$ \\
\hline
\end{tabular}

\subsubsection{Unseen Reading Comprehension Test}

For constructing the unseen reading comprehension test (URCT), five theology texts whose authors were the same as those of the course books were chosen from Abul Quasem (1983), Ahmad (1978), Al-Ghazzali (1980), Arberry (1980), and Hamidullah (1959). These texts were checked to contain no schema types other than those comprising the texts employed in the instructional process. Neither did the selected texts contain any grammatical structures not covered during the course of the study. Table 5 presents the schematic composure of the 5 texts used for the URCT.

Table 5. Descriptive statistics of schema types comprising the unseen reading comprehension test

\begin{tabular}{|l|c|l|l|l|l|}
\hline & $\begin{array}{l}\text { No. of text's } \\
\text { compromising } \\
\text { types }\end{array}$ & $\begin{array}{l}\text { No. of } \\
\text { familiar } \\
\text { types }\end{array}$ & $\begin{array}{l}\text { No. of } \\
\text { unfamiliar } \\
\text { types }\end{array}$ & $\begin{array}{l}\text { \% of } \\
\text { familiar } \\
\text { types }\end{array}$ & $\begin{array}{l}\text { \% of unfamiliar } \\
\text { types }\end{array}$ \\
\hline Text 1 & 173 & 162 & 11 & 0.936 & 0.064 \\
\hline Text 2 & 198 & 183 & 15 & 0.924 & 0.076 \\
\hline Text 3 & 182 & 164 & 18 & 0.901 & 0.099 \\
\hline Text 4 & 206 & 194 & 12 & 0.941 & 0.059 \\
\hline Text 5 & 258 & 237 & 21 & 0.918 & 0.081 \\
\hline
\end{tabular}

The items comprising the URCT were factual, referential and inferential in nature. While factual items require test takers to look for specific facts given in the text, they must match the choices of a referential item with the schemata constituting the text's paragraphs in order to find out which intended schemata they refer to. As the most challenging type of reading ability, however, inferential items call for the test takers' reasoning ability.

\subsection{Procedure}

During the first pilot study learners underwent the translation-based instruction (TBI) of the course book and took a schema-based cloze multiple choice item test (MCIT) at the end. For designing the schema-based cloze MICT, the instructional materials were broken down into semantic, syntactic and parasyntactic schema domains and their genera, species and types were specified with the aid of this categorization, 80-item schema-based cloze MCIT was developed. Learners of two groups took this achievement test as the final course-leaving examination.

The item analysis performed on the schema-based cloze MCIT administered in the pilot 
study showed that seven items out of 80 had inappropriate item difficulty indices, i.e., there were either lower than .25or higher than .85. These items were replaced with other new schema-based items. The revised schema-based cloze MCIT was administered at the beginning of the main study as a pretest to achieve two purposes; first, to find out whether the students of both groups were familiar with the teaching material before the commencement of the treatment, and secondly, to ensure that the learners of SBI and TBI groups did not significantly differ from each other in terms of their reading comprehension ability. At the end of the course, the schema-based cloze MCIT which was previously used as the pre-test was administered again in addition to the unseen reading comprehension test. The comparison of the participants' performances on these two tests made it possible to find out whether the general English learners in the SBI performed significantly higher than their peers in the TBI group as a result of schema-based instruction.

\section{Data Analysis}

The revised schema-based cloze multiple choice item test (MCIT) was administered at the very beginning of the semester as a pre-test. At the end of the course of study, after the application of two instructional approaches for the participants of the TBI and the SBI groups, their performances were compared on MCIT which had been used as the pre-test. Considering the fact that both the pre-test and post-test was administered on the same day for both of the groups, the effect of maturation as an intervening variable was negligible for the study's interpretation. Accompanied by MCIT, participants of both groups were asked to take an unseen reading comprehension test (URCT) at the termination of the semester. The test was constructed out of the similar texts in terms of compromising schemata. These texts were also written by the same authors of the course book. Table 6 shows the descriptive statistics of the applied tests during the study.

Table 6. Descriptive statistics for the schema-based multiple choice item test used as the study's pre-test and post-test and the unseen reading comprehension test

\begin{tabular}{|l|c|c|c|c|c|c|c|c|}
\hline \multicolumn{1}{|c|}{ TEST } & $\begin{array}{c}\text { No. of } \\
\text { items }\end{array}$ & Min. & Max. & Mean & $\begin{array}{c}\text { Std. } \\
\text { Deviation }\end{array}$ & $\begin{array}{c}\text { Mean } \\
\text { p-value }\end{array}$ & Mean $\mathrm{r}_{\mathrm{pbi}}$ & $\alpha$ \\
\hline Schema Pretest & 80 & 0 & 64 & 19.95 & 11.648 & .25 & .34 & .90 \\
\hline Schema Posttest & 80 & 23 & 75 & 53.38 & 12.565 & .66 & .36 & .91 \\
\hline Unseen Reading Test & 35 & 4 & 22 & 12.59 & 3.931 & .36 & .25 & .64 \\
\hline
\end{tabular}

In terms of difficulty, as judged by mean $p$-value, the schema-based MCIT used as the pre-test (.25) was the most difficult. While the schema post-test and unseen reading comprehension tests enjoyed acceptable levels of difficulty. As can be seen in Table 5, both the schema pre-test $(\alpha=.90)$ and the schema post-test test are highly reliable $(\alpha=.91)$. Among the tests administered in the study, the URCT had the lowest reliability coefficient ( $\alpha$ $=.64$ ). This degree of moderate reliability was, nonetheless, acceptable because its length was much shorter than the schema-based cloze MCIT. 
The experimental enquiry started with gaining certitude about the fact that the participants of two study's groups had not been significantly different in terms of reading comprehension proficiency before the application of the study's treatment. Table 7 shows the mean obtained by the two groups on the schema-based cloze MCIT administered as a pre-test.

Table 7. Means comparison of schema-based cloze multiple choice item test a administered as a pre-test

\begin{tabular}{|l|l|c|c|c|c|c|}
\hline \multicolumn{2}{|l|}{} & $\mathrm{t}$ & $\mathrm{df}$ & $\begin{array}{c}\text { Mean } \\
\text { Difference }\end{array}$ & $\begin{array}{c}\text { Std. Error } \\
\text { Difference }\end{array}$ & Sig.(2-tailed) \\
\hline $\begin{array}{l}\text { Schema } \\
\text { pre-test }\end{array}$ & $\begin{array}{l}\text { Equal variances } \\
\text { assumed }\end{array}$ & -1.483 & 85 & -3.685 & 2.484 & .142 \\
\hline & $\begin{array}{l}\text { Equal variances } \\
\text { not assumed }\end{array}$ & -1.457 & 72.393 & -3.685 & 2.529 & .149 \\
\hline
\end{tabular}

As can be seen, there was not a significant difference between the participants of the two study's groups in terms of their general English language proficiency before the application of the SBI $(\mathrm{t}=-1.457, p>0.05)$. This implies that any significant difference on the part of SBI participants on the final MCIT and URCT results would be the consequence of schema-based instruction.

As Table 8 shows, comparing the means of TBI and SBI English learners on the second administration of schema-based cloze MCIT revealed that those participants who had undergone schema-based instruction (SBI) for the course book outperformed remarkably in comparison with their peers who had experienced translation-based instruction (TBI) $(\mathrm{t}=$ -2.247, $p<0.05)$. This finding answers the first research question in the way that there was a statistically significant difference in the performance of translation and schema-based instruction groups on the final schema-based cloze MCIT.

Table 8- Means comparison of schema-based multiple choice item test (MCIT) used as the study's post-test

\begin{tabular}{|l|l|c|c|c|c|c|}
\hline \multicolumn{2}{|c|}{} & $\mathrm{t}$ & $\mathrm{df}$ & $\begin{array}{c}\text { Mean } \\
\text { Difference }\end{array}$ & $\begin{array}{c}\text { Std. Error } \\
\text { Difference }\end{array}$ & $\begin{array}{c}\text { Sig.(2-ta } \\
\text { iled) }\end{array}$ \\
\hline $\begin{array}{l}\text { Schema } \\
\text { post-test }\end{array}$ & $\begin{array}{l}\text { Equal variances } \\
\text { assumed }\end{array}$ & -2.247 & 85 & -5.925 & 2.637 & .027 \\
\hline $\begin{array}{l}\text { Equal variances } \\
\text { not assumed }\end{array}$ & -2.257 & 84.899 & -5.925 & 2.625 & .027 \\
\hline
\end{tabular}

Table 9 shows the comparison of mean scores obtained by the SBI and TBI participants at the study's termination. As can be seen, the $(\mathrm{P}=0.00<0.05)$ SBI English learners were also statistically superior to TBI learners in comprehending unseen related texts $(\mathrm{t}=-2.247, p<$ $0.05)$. Hence, the second research question was answered; there was a statistically significant difference in the performance of translation and schema-based instruction groups on the final unseen reading comprehension test (URCT). 
Table 9. Means comparison of the unseen reading comprehension test (URCT)

\begin{tabular}{|l|l|c|c|c|c|c|}
\hline \multicolumn{2}{|c|}{} & $\mathrm{t}$ & $\mathrm{df}$ & $\begin{array}{c}\text { Mean } \\
\text { Difference }\end{array}$ & $\begin{array}{c}\text { Std. Error } \\
\text { Difference }\end{array}$ & $\begin{array}{c}\text { Sig.(2-ta } \\
\text { iled) }\end{array}$ \\
\hline $\begin{array}{l}\text { Unseen } \\
\text { reading }\end{array}$ & $\begin{array}{l}\text { Equal variances } \\
\text { assumed }\end{array}$ & -5.587 & 85 & -4.058 & .726 & .000 \\
\hline $\begin{array}{l}\text { Equal variances } \\
\text { not assumed }\end{array}$ & -5.489 & 72.657 & -4.058 & .739 & .000 \\
\hline
\end{tabular}

\section{Discussion}

Anderson (1977), an educational psychologist, played an important role in introducing Schema Theory to the educational community. He pointed out convincingly that, schemata provided a form of representation for complex knowledge and that the construct, for the first time, provided a principled account of how old knowledge might influence the acquisition of new knowledge. Schema Theory was consequently applied to understanding and explaining the reading process, where it served as an important counterweight to purely bottom-up and top-down approaches to reading comprehension ability. It is based on the assumption that the ability depends not only on understanding each and every schema in and out of itself, i.e., bottom-up, but also on finding its semantic, syntactic and discoursal relationships with the other schemata comprising the text, i.e., top down. The authors have tried to embody Schema Theory's theoretical principles in a new language instruction approach and explore its efficacy in an academic context.

Considering the fact that speaker/writer's schemata are highly personalized, a perfect comprehension, which is the essence of any educational program, is very remote if not impossible on the part of the readers/listeners. However, Schema Theory does postulate the possibility of achieving perfect comprehension by employing common semantic features constituting the produced schemata and their mutual sharing by interlocutors provided that they establish the same semantic, syntactic and discoursal relationships among the schemata (Khodadady, 2003).

Global word knowledge is crucial to reading comprehension and determines how well students will be able to comprehend the texts they read, however, research findings do show that the knowledge of the words used in the texts are significantly better predictors of reading comprehension ability than the global words (Khodadady 2000) The present study extends the contextual vocabulary knowledge to the semantic, syntactic and discoursal relationships they hold with each other to bring about the comprehension of English texts dealing with theology on a theoretically sound basis.

On the basis of the results of this study, it is revealed that in addition to remarkable outperformance of all participants on the post-test compared with the pre-test on the same test items, the degree of this betterment is significantly higher for SBI participants who have undergone SBI for their general English course. SBI superiority over TBI is also approved by the mean comparison on the participants' performances on the unseen reading comprehension test (URCT). SBI helped English learners understand the implicit meaning and the syntactic 
application of each learnt schema even in unseen texts.

\section{Conclusion}

This study was an attempt to carry out a systematic inquiry on the efficacy of a new instructional approach in an Iranian academic context. Schema-based instruction (SBI) is based on the premise that general English learners should become aware of the existing internal and dynamic relationships among the words constituting a given authentic text. This awareness helps them understand the fact that synonymous and semantically related words have different and unique applications within texts in spite of their common semantic features. Any slight modification in the lexical network of a text may result in a huge interpreting distortion.

This study was designed on the premise that the traditional approaches of teaching general English courses should be replaced by those being based on a theoretically sound and empirically validated basis. This can be achieved through schema-based instruction (SBI) and testing whose superiority in terms of reliability and validity is established by the results obtained in the study. Although some advantages of translation-based instruction (TBI) proposed by Chastain (1971), were previously mentioned (section 2.2), this study validated the superiority OF SBI within an experimental context;

- Grammar-translation method (GTM) gives pupils the misguided idea of what language is and of the relationship it assumes to exist among words in general. Not only is it assumed that language is a collection or words which are isolated and independent from each other but also it hypothesizes a direct correspondence between foreign words and their equivalents in the native tongue. The SBI is, however, based on the premise that the readers of a given text will understand it best if they are familiar with the contextual meaning of each and all words, i.e., schemata, employed by the writer of the text. In better words, a schema-based instructor, instead of leaving the learners to themselves to grapple with the contextual meaning of the schemata and how they relate to each other, discusses the texts in terms of its constituting schemata and focus on their relationships in all possible contexts and modes so that the learner's comprehension of the schemata would approach to that of the writer.

- The GTM is a particular analysis of the written target language, especially its grammar and vocabulary that are learned from bilingual word lists which might be boring as a main task. In addition, students' mother tongue is used as the medium of instruction and thus deprives the learners from any form of listening and speaking activities other than single word pronunciations and reading aloud. As noted by Richards and Rogers (2001), The GTM "does virtually nothing to enhance a student's communicative ability in the language." On the other hand, schema-based instruction (SBI) employs target language from the beginning to the end of instruction and attempts to help the learners improve their schemata by exposing them to the context in which they are used in the texts under comprehension and discuss them interactively to enhance their speaking ability. Future research must show whether 
the SBI brings about significant changes in learners' oral communication as it did with their reading comprehension ability in this study.

The present study investigated the effect of the SBI on reading comprehension ability as a process through teaching and a product through testing and validated its superiority over the TBI. As a linguistic and cognitive process, the ability depends not only on the discoursal relationships present among the schemata constituting given texts but also on the vocabulary and grammatical knowledge of readers. In the teaching process of the SBI learners are also exposed to the meanings of the schemata and their syntactic roles by employing semantics and syntax to assign them to domains, genera, and species. Future research must, therefore, show whether the explicit teaching of schemata meaning and syntax in the foreign language will result in superior performance of learners taught via the SBI.

\section{References}

Abul Quasem, M. (1983). The Jewels of the Quran: Al-Ghazzali's Theory. Kegan Paul International. [Online] Available: http://www.philadelphia.edu.jo/library/200/210HTM.

Ahmad, Kh. (1978). Islam: It's Meaning and Message. Qum: Center of Islamic studies.

Al-Ghazzali, M. (1980). The alchemy of Happiness. London: The Octagon Press. [Online] Available: http:// www. books. google.com/ books? id=MGom6ENJRLkI.

Anderson, R. C. (1977). The Notion of Schemata and the Educational Enterprise. Hillsdale, NJ: Erlbaum. [Online] Available: http://aer.sagepub.com/content/15/3/433.

Arberry, A. J. (1980). The Quran Interpreted. London: George Allen \& Unwin Ltd. [Online] Available: http://www.answering-islam.org/Gilchrist/Vol1/biblio.html

Ataii, M. \& Dastjerdi, H. V. (2002). English for students of theology and Islamic sciences. Tehran: SAMT.

Ausubel D. A. (1968). Educational Psychology: A Cognitive View. New York. [Online] Available: http://www.books.google.ca/books?id=17cdAAAAMAAJ

Bachman, L. F., Davidson, F., Ryan, K., \& Choi, I. (1995). An investigation into the comparability of two tests of English as a foreign language: The Cambridge TOEFL comparability study. Cambridge: Cambridge University Press. [Online] Available: http://1t.sagepub.com/content/25/1/39.

Bartlett, F.C. (1932). Remembering: A Study in Experimental and Social Psychology. Cambridge, England: Cambridge University Press. [Online] Available: http://psycnet.apa.org/psycinfo/1993-17681-001.

Bromberg, M. (2004). 1100 words you need to know (4th Ed.). Barron's publications: USA. [Online] Available:http://www.scribd.com/doc/55713450/americandreambiblioresource.

Carrel, P.L. (1984). The effect of rhetorical organization in ESL readers. TESOL Quarterly, $18,441-476$. 
Chastain, K. (1971). The Development of Modern Language Skills: Theory to Practice. Philadelphia: Center for Curriculum Development.

Driscoll, M. (1977) Psychology of Learning for Instruction. Boston: Allyn and Bacon.

Farhady, H., Jafarpoor, A., \& Birjandi, P. (1994). Testing language skills from theory to practice. Tehran, SAMT.

Gairns, R., \& Redman, S. (1996). True to life: Intermediate class book. Cambridge: Cambridge University Press.

Halliday, M. K. \& Hassan, R. (1989) Language, context, and text: aspects of language in a social-semiotic perspective. Oxford: Oxford University Press. [Online] Available: http://www.books.google.ca/books?id=wuVwAAAAIAAJ.

Hamidullah, M. (1959). Introduction to Islam. Paris: Centre Cultural Islamique. [Online] Available: http://www.books.google.ca/books?id=bUAQAgAACAAJ\&redir_esc=y

Hart, B. \& Risley, T.R. (1995). Meaningful differences. Baltimore: Paul H. Brookes Publishing Co.

Hirsch, E. D. (2003). Reading comprehension requires knowledge of words and the world: Scientific insights into the fourth-grade slump and the nation's stagnant comprehension scores. American Federation of Teachers: American Educator pub.

Howatt, A. (1984). A History of English language teaching. Oxford: Oxford University Press.

Hughes, A. (1989). Testing for language teachers. New York: Cambridge University Press. [Online] Available: http://www.worldcat.org/books?id=18869767.

Kant, I. (1781). Scripts, Plans, Goals and Understanding. Hillsdale, NJ: Erlbaum.

Kaplan, R. (2007). Cultural thought patterns in inter-cultural education. Language Learning, $16,1-20$.

Khemlani, D. (2000). Bartlett's Concept of the Schema and Its Impact on Theories of Knowledge Representation in Contemporary Cognitive Psychology. In Bartlett, Culture and Cognition, ed. Akiko Saito. England: Psychology Press.

Khodadady, E. (1997). Schema theory and multiple choice item tests measuring reading comprehension. Doctoral dissertation. University of Western Australia: Australia.

Khodadady, E. (1999). Multiple choice items in testing: Practice and theory. Tehran: Rahnama.

Khodadady, E. (2000). Contextual vocabulary knowledge: The best predictor of native and non-native speakers' reading comprehension ability. ESPecialist, 21(2), 181-205. [Online] Available: http://www.ojs.gc.cuny.edu/index/lljournal/article id=564/737.

Khodadady, E. (2003). Objective-based achievement testing in the context of schema theory. Paper presented at the $33^{\text {rd }}$ annual conference of Canadian Association of applied linguistics, 
University of Dalhousie, Halifax, Canada.

Khodadady, E. (2008). Schema-based textual analysis of domain controlled authentic texts. Iranian Journal of Applied Linguistics, 11, 25-47.

Khodadady, E., \& Herriman, M. (2000). Schemata Theory and Selected Response Item Tests: From Theory to Practice. In A. J. Kunnan (Ed.), Fairness and validation on language assessment (201-222). Cambridge: CUP.

Khodadady, E., R, Pishghadam \& M. Fakhar (2010). The relationship among reading comprehension ability, grammar and vocabulary knowledge: An experimental and schema-based approach. The Iranian EFL journal, 6 (2), 7- 49.

Kieffer, G. H. (1979). Bioethics. New York. Addison-Wesley publishing company.

Larsen-Freeman, D. (2000). Techniques and principles in language teaching. Oxford: Oxford University Press. [Online] Available: http://www.amazon.com/dp/0194355748.

Morimoto, Sh. \& Loewen, Sh. (2007). A comparison of the effects of image-schema-based instruction and translation-based instruction on the acquisition of L2 words. Language Teaching Research, 11(3), 347-372. http://www.dx.doi.org/10.1990/mar. 8336470284953.

Neisser, U. (1967). Cognitive Psychology. New York: Appleton-Crofts.

Palestina, S. (2000). Native Spanish-speaking children reading in English: toward a model of comprehension. Journal of Educational Psychology, 97(2), 246-256.

Piaget, J. (1973). Considerations of Some Problems of Comprehension. New York: Academic University Press.

Quirk, R., Greenbaum, S., Leech, G., \& Svartvik, J. (1985). A comprehensive grammar of the English language. London: Longman.

Richards, J. C. and Rodgers, T. S. (2001). Approaches in methods in language teaching. Cambridge: Cambridge University Press. [Online] Available: http://www.cal.org/resources/archive/rgos/methods.html

Schmitt, N. (1997). Vocabulary Learning Strategies. Vocabulary: Description, Acquisition and Pedagogy, 3, 199-227.

\section{Appendix}

Appendix 1. Schema-based cloze multiple choice item test

Direction: Read the passages below and choose the best answer marked A, B, C and D. After choosing the best answer, fill in the box corresponding to the number of question in your answer sheet.

Passage 1:

A third reason for the importance of this subject is the ....1...of many religions in different parts of the world. With the ....2...of nationalism and the recovery of self-government, many 
eastern lands have ....3....again to the religion on which their culture has been based. With the example of Christian missions before them Buddhism and Islam, themselves historically ....4.....religions, have begun to send literature and envoys to other peoples. Even in Hinduism and Sikhism a similar ....5.....and outward looking is apparent. The modern world has not yet done ...6....religion. Our scientific age, with its ...7....and its uncertainties, is ....8....just beginning to realize the strength of the faiths that men have held ...9.... for thousands of ...10... and that are reviving today.

$\begin{array}{lllll}1 & \text { A. stimulation } & \text { B. revival* } & \text { C. reinforcement } & \text { D. recovery } \\ 2 & \text { A. climb } & \text { B. mount } & \text { C. rise* } & \text { D. ascend } \\ 3 & \text { A. bowed } & \text { B. crooked } & \text { C. turned* } & \text { D. curved } \\ 4 & \text { A. disciple } & \text { B. follower } & \text { C. messenger } & \text { D. missionary* } \\ 5 & \text { A. developing } & \text { B. stirring } & \text { C. beginning } & \text { D. awakening* } \\ 6 & \text { A. by } & \text { B. among } & \text { C. with* } & \text { D. through } \\ 7 & \text { A. pride* } & \text { B. satisfaction } & \text { C. pleasure } & \text { D. arrogance } \\ 8 & \text { A. barely } & \text { B. simply } & \text { C. only* } & \text { D. uniquely } \\ 9 & \text { A. sweetheart } & \text { B. darling } & \text { C. dear* } & \text { D. beloved } \\ 10 & \text { A. years* } & \text { B. days } & \text { C. centuries } & \text { D. months }\end{array}$

Passage 2:

These pre-literary religions are often ...11...in comparative works of this ....12..., or they may be dismissed as '...13....'. But this word is ambiguous. It suggests that the religious manifestations are ...14 or materialistic and even more that we can see in them the ...15... the religion first took when it appeared ...16... men. This assumption is quite arbitrary, for there is. $.17 \ldots$ evidence that backward people today hold the same beliefs as did the first prehistoric men to show ...18... of religious ideas. All modern ....19... have a history, even where that history is ....20.... and largely unknown. They are modern men, not primordial beings.

$\begin{array}{lllll}11 & \text { A. deserted } & \text { B. neglected* } & \text { C. mistreated } & \text { D. cared for } \\ 12 & \text { A. class } & \text { B. manner } & \text { C. kind* } & \text { D. brand } \\ 13 & \text { A. ancient } & \text { B. archaic } & \text { C. primitive* } & \text { D. historic } \\ 14 & \text { A. basic } & \text { B. simple } & \text { C. unfinished } & \text { D. crude* } \\ 15 & \text { A. forms* } & \text { B. shapes } & \text { C. moods } & \text { D. patterns } \\ 16 & \text { A. among* } & \text { B. between } & \text { C. with } & \text { D. along } \\ 17 & \text { A. slight } & \text { B. small } & \text { C. little* } & \text { D. tiny } \\ 18 & \text { A. ciphers } & \text { B. symbols } & \text { C. codes } & \text { D. signs* } \\ 19 & \text { A. aristocrats } & \text { B. workers } & \text { C. peoples* } & \text { D. soldiers } \\ 20 & \text { A. undisclosed } & \text { B. unheard } & \text { C. unwritten* } & \text { D. uncovered }\end{array}$

\section{Passage 3:}

What will become of man if his life is devoid of belief in a(n) ...21... life in the hereafter? Belief in the continuity of life in the next world is a(n) ...22... concept. Under its impact, man's life $\ldots 23 \ldots$ earth assumes new dimensions opening higher horizons of $\ldots 24 \ldots$ before 
him, in the absence of which he is inevitably oppressed by a(n)...25... sense of nothingness, as it means a virtual cutting short of man's total life-span, making him a mere plaything in the hands of his whims and caprices which teach ....26... nothing but to derive the maximum ...27....amount of pleasure during this short sojourn upon the earth. Mutual rivalries, savage battles and conflicts over the possession of ...28... gains follow, as there is no higher power to control and restrain one's desires. Blinded by greed and lust, man tries to gain ...29... he can in the shortest span of time. His total perspective of life and its mission is lost altogether. This degrades man to lower planes of feelings and thought. His .....30...sinks low and so do his ideals and the means to achieve them. Mankind is doomed to a perpetual life of hideous internecine wars that scarcely permit it to pursue higher and nobler ends in life.

$\begin{array}{lllll}21 & \text { A. confidential } & \text { B. continual } & \text { C. eternal* } & \text { D. perpetual } \\ 22 & \text { A. evolutionary } & \text { B. active } & \text { C. revolutionary* } & \text { D. shattering } \\ 23 & \text { A. up } & \text { B. upon* } & \text { C. into } & \text { D. among } \\ 24 & \text { A. improvement } & \text { B. movement } & \text { C. advancement } & \text { D. progress* } \\ 25 & \text { A. indirect } & \text { B. twisted } & \text { C. tortuous* } & \text { D. painstaking } \\ 26 & \text { A. him* } & \text { B. her } & \text { C. its } & \text { D. their } \\ 27 & \text { A. promising } & \text { B. likely } & \text { C. probable } & \text { D. possible* } \\ 28 & \text { A. material* } & \text { B. substance } & \text { C. matter } & \text { D. object } \\ 29 & \text { A. wherever } & \text { B. whenever } & \text { C. whatever* } & \text { D. whoever } \\ 30 & \text { A. head } & \text { B. mind } & \text { C. thought* } & \text { D. imagination }\end{array}$

\section{Passage 4:}

Islam is based on the ...31... relation between God and man, God in His absoluteness and man in his $\ldots 32 \ldots$ theomorphic nature. Islam bases the realization of this ...33... relationship on the intelligence, will and speech and consequently on ....34... and certitude. It has sought to establish equilibrium in life by channeling all of man's natural needs and inclinations, all those natural desires and needs such as that for food, shelter, procreation, etc. given by God and ...35 ... in human life, through the divine law or shariah. And upon the firm foundations of this equilibrium, Islam has enabled man to build a spiritual castle based on ....36.... and the certainty that there is no divinity other than the Absolute. In this sense its ....37... is in contrast to Christianity in which love plays the central role and sacrifice is the outstanding ....38.... For this very reason, Christians have often criticized Islamic virtues as being ....39.... and contributing simply to a special equilibrium whereas the Christian love of sacrifice seems to a Muslim as a kind of ...40..... which breaks the universal relationship between what is natural in man and the divine being.
31 A. widespread
B. collective
C. universal*
D. total
32 A. profound*
B. weighty
C. intense
D. philosophical
33 A. inner
B. mid
C. innermost
D. central*
34 A. equilibrium*
B. permanence
C. continuum
D. balance
35 A. obligatory
B. mandatory
C. necessary*
D. compulsory
36 A. observation
B. deliberation
C. inspection
D. contemplation* 


$\begin{array}{lllll}37 & \text { A. method* } & \text { B. way } & \text { C. scheme } & \text { D. manner } \\ 38 & \text { A. advantage } & \text { B. worth } & \text { C. virtue* } & \text { D. value } \\ 39 & \text { A. middling } & \text { B. pedestrian } & \text { C. mediocre* } & \text { D. average } \\ 40 & \text { A. individualism* } & \text { B. selfishness } & \text { C. independence } & \text { D. egoism }\end{array}$

Passage 5:

Through belief in the ...41....of God, Who is invested with all the attributes of perfection, Islam seeks to ...42... human intellect of the filth of ...43 ... and superstitious fancies. In fact, polytheism and idolatry which are opposed by Islam...44... man to a level which is incompatible with his dignity. Islam fights ...45... idolatry and polytheism in whichever forms and to whatever extent they might be found. In its concern to eradicate idolatry, Islam takes notice ....46... of imperceptible forms of idolatry. It takes notice even of those beliefs and practices which do not appear to their adherents....47... tainted with idolatry. One of the manifestations of this concern is that Islam does not permit man to...48... in the name of anyone except God. All this is owing to the uncompromising hostility of Islam to idolatry. In fact, by destroying ...49... which might blur the distinction between the ...50... and the Creator, Islam has brought man out of the darkness of superstition and ignorance to the full daylight of realities.

$\begin{array}{lllll}41 & \text { A. unity* } & \text { B. unison } & \text { C. union } & \text { D. unanimity } \\ 42 & \text { A. omit } & \text { B. purge* } & \text { C. eliminate } & \text { D. remove } \\ 43 & \text { A. idolization } & \text { B. adulation } & \text { C. idolatry* } & \text { D. adoration } \\ 44 & \text { A. debase } & \text { B. dishonor } & \text { C. degrade* } & \text { D. disgrace } \\ 45 & \text { A. next to } & \text { B. beside } & \text { C. against* } & \text { D. before } \\ 46 & \text { A. still } & \text { B. yet } & \text { C. even } & \text { D. just* } \\ 47 & \text { A. because } & \text { B. since } & \text { C. like* } & \text { D. as } \\ 48 & \text { A. swear* } & \text { B. declare } & \text { C. undertake } & \text { D. pronounce } \\ 49 & \text { A. everything } & \text { B. anything* } & \text { C. something } & \text { D. nothing } \\ 50 & \text { A. being } & \text { B. creature* } & \text { C. individual } & \text { D. man }\end{array}$

Passage 6:

The covenant made between man and god by virtue of ...51... man accepted the trust (amanah) of being an intelligent and free being with all the opportunities and dangers that such a(n) ...52 ... implies, is symbolized physically by the stone of the Kaba. Spiritually the ...53 ... of this covenant is contained in the Quran, that central theophany of Islam which is itself the ...54.... expression of this eternal covenant between God and Man. In the Quranic verse 'Am I not your ...55...?' (7:172), God proposes to man even ....56....the beginning of historical time and the creation of the earth this covenant and in answering 'yes we ...57...', man takes up the challenge of this invitation, and agrees to bear this trust as the servant of his lord $(a b d)$. In this 'yea' lies the ....58 ... and the particular significance of human ....59....., of the life of this theomorphic being ....60... is God's vicegerent or khalifah on earth.
51 A. what
B. which*
C. who
D. where 
52 A. liability

B. dependability

C. responsibility* 2012, Vol. 4, No. 1

53 A. trace

B. record*

C. registration

D. blame

54 A. moving

B. beautiful

C. eloquent*

D. translation

55 A. Lord*

B. Creator

C. Compassionate

D. strong

56 A. by

B. between

C. before*

D. Omniscient

57 A. swear

B. promise

C. show

D. beside

58 A. secret*

B. covert

C. furtive

D. testify*

59 A. continuation

B. survival

C. existence*

D. chicanery

60 A. whom

B. what

C. which

D. presence

D. who*

\section{Passage 7:}

Those revelations are recorded in the Quran, the Holy Book of Islam. Allah has no ...61....attributes. He has no age, no shape, no mother, and no appetites: but neither is He an abstraction. He is a(n) ...62... and constant presence, cognizant of ...63....person's deeds and thoughts, aware of who follows His ...64..... and who does not. Those commands require ...65.... of Mohammad s (S) message, social justice, personal ...66...., respect for others, and restraint of ...67.... desires, as well as the performance of devotional duties ...68.... as prayer and fasting. Islam is an Arabic word that means ....69...., submission to the will of God. Muslim, or Moslem, its participial form, means one ....70.....submits.
61 A. physical*
B. substantial
C. bodily
D. corporeal
62 A. abrupt
B. urgent
C. immediate*
D. direct
63 A. other
B. every*
C. no
D. any
64 A. tips
B. information
C. commands*
D. guidelines
65 A. reception
B. getting
C. taking
D. acceptance*
66 A. openness
B. integrity
C. honesty*
D. frankness
67 A. worldly*
B. earthly
C. global
D. secular
68 A .just
B. such*
C. both
D. then
69 A. submission*
B. capitulation
C. surrender
D. give up
70 A. whom
B. who*
C. which
D. what

Passage 8:

The Quran came to pay so great a(n) ...71... on the unity of God both in His essence and $\ldots . .72 \ldots$ that it blocked for ever all avenues for polytheism and like ...73.... It is this which constitutes its principal ....74.... to the concept of God. The Quran asserts that God alone is ....75... of worship. If you turn to any other in devotion you cease to be a believer in the unity of God. It says that he is who answer the cry of man and fulfills his prayers. So, if you ...76... any other with Him in your prayers you ...77 ... associate that ...78... with him in your prayers. You simply associate that one in the ....79... of attributes of God. Indeed, your belief itself in the unity of God gets ...80...
71 A. importance
B. highlighting
C. accent
D. emphasis*
72 A. distributions
B. attitudes
C. attributes*
D. contributions 
73 A. abnormality

74 A. input

75 A. precious

76 A. correlate

77 A. minimally

78 A. other*

79

80
B. anomaly

B. donation

B. worthy*

B. combine

B. only

B. another

B. religion

B. tainted*
C. peculiarity

C. payment

C. commendable

C. associate*

C. simply*

C. every

C. theology

C. polluted
D. aberration*

D. contribution*

D. admirable

D. bracket

D. diminutively

D. any

D. divinity*

D. infected

Appendix 2. Unseen reading comprehension test

Direction: Read each passage carefully, choose $a, b, c$ or $d$ which best completes the following items and tick the corresponding box in your answer sheets.

\section{Passage 1:}

The starting point of Islam is the belief in the unity of God (towhid). The second is that God has not left man without any guidance for the conduct of his life. He has revealed His guidance through His prophets and Mohammad (S) was the last prophet. And to believe in a prophet means to believe in his message, to accept the law which he gave and to follow the code of conduct which he taught. Thus the second basic postulate of Islam is to believe in the prophethood of Mohammad (S), to accept the religion which he presented and to follow his commands.

Every prophet of God, according to Quran, strove to build man's relationship with God on the principle of God's sovereignty and the acknowledgment of the authority of the prophet as the source of divine guidance. Every one of them said: "I am to you God's apostle, worthy of all trust. So be committed to God, fear him, and obey me." The guidance is revealed through the prophets. It is a part of their mission to translate it into practice, in their own lives and in the society they try to reform. All the prophets are representatives of God, but they are human beings and their lives are models for mankind. Mohammad (S) as the last prophet is representative of the Supreme Ruler and we have to follow his example in thought and behavior. The code of behavior, the law which is to decide the lawfulness or otherwise (halal and haram) of things, is given by God through the prophet and is known as the shariah.

Belief in the prophet involves acceptance of the shariah, (the path) he has conveyed and the implementation of that in all walks of life. This is how the will of God is fulfilled on the earth. The Quran says:"We sent not ever any messenger, but that he should be obeyed, by the leave of God." (4: 64). And about the last prophet it explicitly states that: "O believers, obey God, and obey the messenger and those in authority among you. If you should quarrel on anything, refer it to God and the Messenger, if you believe in God and the Last Day; that is better, and fairer in the issue." (4: 62). The test of acceptance of God and His prophet lies in conducting all human affairs in accord with the law revealed by them. Thus, belief in God and His prophet means commitment to obey them both in individual and collective life.

1. The second basic postulate of Islam is 


\section{Macrothink}
A. to believe in the prophethood of Mohammad (S) as the final arbiter
B. to accept the religion which the prophet $(\mathrm{S})$ presented
C. to follow the Prophet's (s) commands
*D. all of the above

2. All the prophets

*A. called people to God's authority

B. taught some postulates of Islam

C. were committed to God and the people

D. believed in the prophethood of Mohammad (s)

3. The code of behavior

*A. is the heavenly law by which one can judge the lawfulness of things

B. has to be implemented in all one's life without asking any questions

C. has to be followed as part of the Islamic shariah

D. is one of the main requirements of the belief in God

4. The will of God is fulfilled on the earth through

A. practicing the goodness in all walks of life

*B. acceptance of the shariah and application of it in all men's life

C. imitating the final model of the prophets for man kind

D. Approval of the sanction made by God for the prophet of Islam

5. According to the Quran, disbelievers
A. submit to Prophet's (S) decision whole-heartedly
B. accept the Prophet (S) as the final arbiter
C. on the basis of their own wisdom

*D. make their decisions in opposition with that God has revealed

6. Which word is closest in meaning with the underlined word in the last paragraph?
A. submission
B. degradation
C. abortion*
D. execution

7. What would the best title for this passage be?
A. Islam, the last religion
*B. Prophethood
C. Believers in prophets
D. Islam starting point 
Passage 2:

"The 'Last Day' is a basic article of Islamic faith, along with 'God, His angels, His books, and His messengers'. (Quran 4: 136). The Quran discusses what occurs after death in detail unparalleled by other scriptures. Hence, scholastic theologians, philosophers, and mystics not to speak of Quran commentators - all have made eschatology one of their principal concerns. The term Maad (return or place of return), used generically for discussions of eschatological realities and events, is derived from the Quranic verses as "What, when we are bones and broken bits ... Who will cause us to return? Say: He who created you the first time." (17: 49-51)

Systematic discussions of maad are often paired with studies of a second concept, al - mabda (origin or place of origin), for, as the Quran affirms, "As He originated you, so you will return." (7: 29). Works on 'the Origin and the Return' deal with such questions as the nature of the human being and his relationship with God, the reason for man's creation, his ultimate good and the manner in which he can achieve it, the various types of individuals that make up the human race and their respective lodging places in the next world, the ontological distinctions between this world and the next, and the interpretation of the data found in the Quran and the hadith concerning death, resurrection, heaven and hell.

In a wider context,' the Origin and the Return' covers everything that touches upon the manner in which man can achieve his proper place in creation or attain human perfection, whether moral, spiritual, or intellectual. In this sense, jurisprudence (fighh) can be considered a branch of eschatology, since the shariah is the sin qua non in the path of human perfection. In the domain of philosophy, ethic describes the human qualities that bring about the 'practical' (as opposed to the 'theoretical') perfection of the soul, while in Sufism lengthy discussions of the spiritual stations play a similar role. Even politics which describes the ideal human society and the means to achieve it can be considered a branch of eschatology; since man's temporal good can be understood only in terms of his eternal good. In short, the ramifications of eschatological teaching are so broad that it is difficult to study anything Islamic without touching upon them.

8. It is difficult to study anything Islamic without touching upon
A. jurisprudence
B. ethics
*C. eternity of life
D. Sufism

9. Man's worldly good can be understood in terms of his
A. spiritual station
*B. otherworldly good
C. perfection of the soul
D. belief in Sufism

10. The ontological distinctions between this world and the next fall in the domain of
A. the Return
B. the Origin 
*C. the Origin and the Return

D. the philosophy of Sufism

11. The main Idea of the text is

A. all created things are subject to death and resurrection

B. eschatology is an inseparable part of life on earth

*C. in Islam, everything goes around the issue of resurrection

D. man's creation is as important as his resurrection

12. In Sufism, practical perfection of the soul can be gained through
*A. lengthy discussions
B. spiritual stations
C. acts of worship
D. the realization of spiritual stations

13. Which word is closest in meaning with the underlined word in the second paragraph?
*A. created
B. helped
C. saved
D. faded

14. Why can be politics considered as a branch of eschatology?

A. because both have the same final aim for man's life

*B. because temporal good can be defined based on the perpetual good

C. because both have been revealed by God to man

D. because both are everlasting concepts

\section{Passage 3:}

The word 'Imam' literally means leader or guide, and in its specifically Shiite meaning, it signifies him who is ordained by God to continue divine guidance after prophecy has come to an end. This is also called 'wilayah', which has almost the same meaning as the 'imamate', but 'wilayah' emphasizes more particularly that special quality of the imam with which he is endowed by God to interpret the inner or esoteric meaning of revelation. 'Wilayah' literally means to be friend or to be nearer to someone; hence, the 'wali', in Shiite terminology, is he who is nearest to God in love and devotion and therefore is entrusted by Him with the esoteric knowledge of religion. The imams are thus the 'awliya' Allah par excellence.

The 'imamate' is based on two principles: 'nass' and 'Ilm'. 'Nass' means that the imamate is a prerogative bestowed by God upon a chosen person from the family of the Prophet(S), who, before his death and with the guidance of God, transfers it to another by an explicit designation, 'nass'. In order to continue the divine guidance necessary for mankind, the first 'nass' was initiated by the Prophet(S) himself who, before his death and under the divine command, designated Ali ibn Abi Talib (AS) as his successor. On the authority of 'nass', therefore, the imamate is restricted, through all political circumstances, to a definite individual from among the descendants of Ali (AS) and Fatemah (SA), whether he claims 
temporal rule for himself or not.

The second principle embodied in the doctrine of the imamate is that of 'ilm'. This means that an imam is a divinely inspired possessor of a special sum of knowledge of religion not possessed by anyone else, which can only be passed on before his death to the following imam. In this way the imam of the time becomes the exclusive, authoritative source of knowledge in religious matters, and without his guidance no one can keep to the right path. The doctrine or the imamate in Twelver Shiism thus rotates around these two principles, 'nass' and 'ilm', which are not merely conjoined or added to each other, but are so thoroughly fused into a unitary vision of religious leadership that it is impossible to separate the one from the other.

15.'Wali' in Shiite terminology refers to the person
A. chosen by people from among the Prophet's family (SA)
B. entrusted by God from among knowledgeable people
C. chosen only by Prophet (S) from among his family
*D. equipped by God with the impenetrable knowledge of religion

16. According to the principles of imamate, the imam before his death.........
*A. declares his successor clearly
B. transfers imamate to another
C. announces the Prophet's(S) designation
D. chooses his eldest son

17. When prophecy came to an end, the Prophet (S)

A. invited the descendants of Ali (AS) and Fatemah (SA) to designate the first imam

*B. himself announced Ali (AS) as his successor under Allah's command

C. let 'awliya' Allah choose an individual based on 'nass' and 'ilm'

D. suggested imam Ali (AS) to God as his successor

18. According to the principles of 'ilm', an imam...........
A. enjoys having as much knowledge of religion as his predecessor had
B. passes part of his knowledge before his death to the following imam
C. possesses knowledge of religion more than anyone else has
*D. is the exclusive, authoritative source of knowledge of his own age
19. The main idea of the last paragraph is.
A. the transmission of knowledge through imamate
B. the legitimacy of imamate after Ali (AS)
C. the transfer of imamate among the Prophet's family (SA) 
*D. the unitary concept of religious leadership in Islam

20. Which word is closest in meaning with the underlined word in the second paragraph?
A. possibility
*B. right
C. doctrine
D. guidance

21. What would the best title for this passage be?
A. Knowledge transmission
B. Prophet's designation
*C. Imamate
D. The Twelver Shiism

\section{Passage 4:}

What is just? What is unjust? These questions are the basis for political and legal thought. The laws laid down by governments ought to be just, and they ought to be administered fairly. Lawyers' minds have generally been fixed on the second question; political scientists, on the first. However, the basic questions are the same: what is just? and what is unjust? Here, of course, efforts will be made to find answers to the above questions from the Islamic viewpoint. The Islamic holy constitution has placed significant emphasis on justice as one of the most important aspects of personal faith because of its deep involvement with the moral values of ideological belief. The broad concept of justice presented and dealt with in the Islamic holy constitution is an extensive topic and, because of this, only an outline will be presented to show how justice is relevantly connected to personal faith in God. Even though the Islamic holy constitution has spelled out many examples of justice and injustice in different events and it contains strict regulations concerning certain capital crimes, there has not been a clear definition of what is just and what is unjust. Because the aspect of justice cannot be precisely and materially defined, it has been emphatically connected with individual faith and moral conduct. Thus, the Islamic holy constitution has declared in the Prophetic Sunnah (traditions) that: "He will never be a believer, who does not love for his brother whatsoever he loves for himself." This general measurement of personal faith indicates that justice cannot be conceptualized materially by a precise definition. Moreover, each aspect of justice has so many different phases that can be determined only by circumstantial evidence and not by plain definition.

Regardless of this ambiguity concerning justice, the command for justice has to come directly from God Himself instructing mankind to act justly towards others in joint practices designed to promote common or complementary interests. The following verses of the Holy Quran emphasize this very juice of the concept of justice in Islam:

"O believers, be you securers of justice, witnesses for God, even though it be against yourselves, or your parents and kinsmen, whether the man be rich or poor; God stands closest to either. Then follow not caprice, so as to swerve; for if you twist or turn, God is aware of the things you do." (4:135)

22. The questions of 'what is just?' and what is unjust?'

A. are answered in the same way by lawyers and politicians 
*B. have various answers for different people

C. are not dependent on individual person's faith in God

D. have ambiguous answers in the Islamic holy constitution

23. The Islamic holy constitution considers justice.....

A. in connection with clear definitions of just and unjust

*B. as a significant aspect of individual faith

C. in connection with philosophical and natural aspects

D. as an emphatic material concept

24. According to Islamic principles, the call for justice is made directly by.....
A. the prophet
B. every angel
C. all believers
*D. The Creator

25 . The concept of 'justice' cannot be defined precisely because.......

A. people override other individuals' rights

$B$. there isn't any strict regulations concerning crimes

${ }^{*} \mathrm{C}$. it is relative concept and has many dimensions and aspects

D. people are admonished not to define it materialistically

26. According to Quran, believers should be securers of justice even if......

A. it is not necessary

B. it is very hard

C. it is impossible

*D. it be against yourselves or your parents and kinsmen

27. Which word is closest in meaning with the underlined word in the second paragraph?
*A. structure
B. dependence
C. elements
D. management

28. Which of the following phrases do you suggest as the passage title?
A. Islamic constitution
B. Different views toward justice
${ }^{*}$ C. Justice in Islam
D. Prophets' justice

\section{Passage 5:}

Man's superiority over the lower beings lies in his reason, and the key of his happiness or unhappiness, his perfection or lack of it, is entrusted to the power of his own competence. If he will choose to walk upon the straight path of good deeds and of knowledge, he can advance himself stage by stage, because of the struggle towards perfection which lies in his 
nature. Thus, he may reach the place where the light of God shines upon him, where he finds approach to the highest asylum. If, however, he is passive and allows his nature to have control over him, then he will follow the downward path and his destructive passions will take possession of him. What he chooses is left to man's reason. He may succumb to the lowest 'spirit' in him, namely the bestial, or to the middle, which is feral, or to the highest, which is that of the angels. These are mentioned in the Quran as the 'commanding', the 'blaming' and the 'confident' spirits respectively.

The aim and object of man's life is the attainment of perfection. It is an aim that lies within the compass of man's powers and if he interprets his conceptions in action to the limit of his capacity, then perfection is attained. The perfect or complete man is he who has achieved enduring existence in happiness and finds his felicity in God's commands. Between him and God there will be no evil interposed and in the glory of God's proximity he will find the greatest extreme of happiness.

According to the pre-Aristotelians, happiness was purely a function of the soul. The post-Aristotelians, such as the Stoic philosophers, made happiness a function of the body as of the mind. But that means considering happiness, which is the noblest of things and utterly free from any hint of change or evanescence, dependent upon a contemptible thing like the body and so making it contingent upon chance and accident. Aristotle himself, who had observed the variety of mankind and the differences of man's views with regard to happiness,

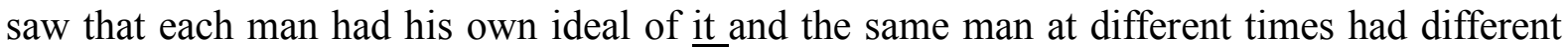
ideals. He therefore divided happiness into five parts (health of body being the first), the lack of any one of which made perfect happiness impossible.

On the question whether happiness is to be attained in this world or is to be looked for in the next, the opinion of the older philosophers is that the body is the veil of the soul, which alone could appreciate happiness and that therefore it is only with the destruction of the body that happiness can be achieved. Aristotle said it would be a vile thing were we to say that in this world a man may be a true believer in God and constant in well-doing and yet can be accounted happy only when he and his good deeds perish. The philosopher's view is that there are grades of happiness to be achieved here according to one's effort. The absolutely happy man is he whose happiness does not cease or change and who preserves his equanimity under the vicissitude of fortune. The possessor of such happiness, so long as he is in this world, is in the power of external influences and of the heavenly bodies, and the stars of his good or ill fortune are all about him. But although he may be associated with his fellow-men in misfortune, no ill can cast him down, for he is immune against harm from outside influence.

29. Man will fall to destruction if he........
A. yields to his blaming spirit
*B. lets his nature control him
C. approaches the highest asylum
D. keeps away from the straight path

30. Man's highest degree of happiness lies in his 

A. pursuit of knowledge
B. good deeds
C. confident spirit
*D. proximity to God

31. Regarding happiness as a function of the body means........

*A. leaving it to chance and accident

B. making it free from any chance

C. letting it loses its noble nature

D. changing it to a contemptible thing

32. Aristotle considers it bad to say that man can be
A. a believer in God as well as happy in this world
*B. a constant well-doer as well as happy in this world
C. a believer in God here and happy only in the hereafter
D. a well-doer here and a true believer in the hereafter

33. The possessor of absolute happiness is
A. subject to all misfortunes
B. subject to his own feelings
C. safe against all misfortunes
*D. safe against all ills

34. What does the underlined pronoun in the third paragraph refer to?
A. ideals
B. difference
${ }^{*}$ C. happiness
D. hereafter

35. What is this passage mainly about?
A. different views of happiness
*B. how to get the real happiness
C. Aristotle
D. different types of spirit man may have 